\title{
Optimisme dan Dukungan Sosial terhadap Self-Efficacy Anak Jalanan
}

\author{
Dhio Adityawarman \\ Fakultas Psikologi UIN Syarif Hidayatullah Jakarta \\ dhio.aditya15@mhs.uinjkt.ac.id
}

\begin{abstract}
The study aims to determine whether there is a link between optimism and social support for self-efficacy in street children. 103 adventure samples of street children taken from seven open houses spread in DKI Jakarta and Tangerang. This study uses a non-probability sampling technique, using a purposive sampling method. Test the validity of measuring instruments using confirmatory factor analysis (CFA) techniques, while the data analysis in this study uses multiple regression analysis techniques in SPSS. The results showed that there was a significant influence of optimism and social support on the self-efficacy of street children with $R$-square 0.729. Hypothesis test results found that there is one dimension of optimism that is needed significantly to self-efficacy of street children, which is permanent, and there is one dimension of social support that is significantly related to self-efficacy of street children, namely search and instrumental assistance.
\end{abstract}

Keywords: Self-efficacy, optimism, social support, street children

\begin{abstract}
Abstrak
Penelitian ini bertujuan untuk mengetahui apakah ada pengaruh antara optimisme dan dukungan sosial terhadap self-efficacy pada anak jalanan. Sampel berjumlah 103 anak jalanan yang diambil dari tujuh rumah singgah yang tersebar di DKI Jakarta dan Tangerang. Penelitian ini menggunakan teknik non-probability sampling, dengan menggunakan metode purposive sampling. Uji validitas alat ukur menggunakan teknik confirmatory factor analysis (CFA), sementara analisis data dalam penelitian ini menggunakan teknik analisis regresi berganda dalam SPSS. Hasil penelitian ini menunjukan bahwa ada pengaruh yang signifikan dari optimisme dan dukungan sosial terhadap self-efficacy anak jalanan dengan $R$-square 0,729. Hasil uji hipotesis minor ditemukan bahwa terdapat satu dimensi dari optimisme yang berpengaruh secara signifikan terhadap self-efficacy anak jalanan, yaitu permanence, dan terdapat satu dimensi dari dukungan sosial berpengaruh secara signifikan terhadap self-efficacy anak jalanan, yaitu dukungan nyata atau instrumental.
\end{abstract}

Kata kunci: Self-efficacy, optimisme, dukungan sosial, anak jalanan 


\section{Pendahuluan}

Anak jalanan yang sebagian besar hidupnya berada di jalan secara simultan terpapar oleh lingkungan jalanan. Lingkungan yang apatis, keras, dan eksploitatif hampir selalu dihadapi oleh anak jalanan (Astuti, 2004). Namun dari kehidupan jalanan yang keras, anak menjadi pribadi yang kuat dan berkeinginan keras untuk maju serta memperbaiki kehidupan mereka. Berbagai macam stimulasi dari lingkungan jalanan inilah yang selanjutnya membentuk persepsi anak jalanan tentang situasi pembelajaran (Walgito, 2010).

Lima variabel telah digunakan untuk menyelidiki kondisi anak jalanan. Variabel tersebut adalah hope, resiliensi, self-esteem, dan self-efficacy (Sanji, 2018). Pada penelitan ini, penulis memilih variabel self-efficacy untuk diteliti lebih lanjut. Sanji (2018) menjelaskan bahwa self-efficacy memberikan anak jalanan kesempatan untuk melakukan tugas dalam jangkauan kemampuan mereka, kemudian self-efficacy akan semakin kuat jika LSM dan pemerintah membuka peluang bagi anak-anak setelah program studi mereka.

Teori self-efficacy telah banyak dipelajari dalam berbagai bidang psikologi. Teori ini telah banyak mengalami perkembangan dari pengembang awal teori yaitu Bandura (1997) yang selfefficacy yang mendefinisikan keyakinan akan kemampuan individu untuk dapat mengorganisasi dan melaksanakan serangkaian tindakan yang dianggap perlu untuk mencapai suatu hasil yang diinginkan. Keyakinan ini akan menentukan pola pikir, bagaimana individu berperilaku dan reaksi emosional dalam berbagai situasi. Individu akan menghindari situasi yang mereka yakini tidak mampu menangani. Tingkat self-efficacy mereka akan menentukan seberapa banyak usaha yang mereka lakukan dan seberapa lama bertahan dalam menghadapi kegagalan.

Salah satu faktor internal yang mungkin memengaruhi self-efficacy pada anak jalanan adalah optimisme. Alfianita (2016) menjelaskan bahwa optimisme merupakan suatu pertahanan diri yang dilakukan oleh anak jalanan untuk meningkatkan keyakinan dan melakukan suatu perubahan yang lebih baik di masa yang akan datang. Hasil dari penelitiannya menunjukkan bahwa anak jalanan memiliki optimisme yang ditunjukkan oleh anak jalanan dengan berusaha sungguh sungguh dan kerja keras. Usaha dan kerja keras yang ditunjukkan anak jalanan membuat mereka yakin bahwa dirinya dapat menjadi lebih baik. Sikap optimis yang berisi daya tahan dan daya juang dapat membuat anak jalanan bertahan saat kesulitan datang dan berusaha untuk menyelesaikan masalah sebaik mungkin.

Yeo (2012) menemukan hubungan yang signifikan antara optimisme dan self-efficacy dengan arah positif. Partisipan dalam penelitian tersebut adalah 533 siswa kelas tujuh: 294 anak laki-laki (usia rata-rata 12,9 tahun, $\mathrm{SD}=0,34$ ) dan 239 anak perempuan (usia rata-rata 12,9 tahun, $\mathrm{SD}=$ 0,44). Seluruh dimensi optimisme pada penelitian tersebut yaitu permanence, pervasiveness, dan personalization berkorelasi positif dengan variabel self-efficacy. Anak dan remaja yang memberikan makna positif dari setiap peristiwa dalam hidupnya cenderung memiliki self-efficacy yang tinggi. Optimisme anak dan remaja tercermin pada kepercayaannya yang penuh semangat dalam memenuhi harapan-harapan dalam kehidupannya.

Berdasarkan penelitian yang dilakukan oleh Multasih (2013), terdapat beberapa dukungan yang didapatkan oleh anak jalanan yaitu kepedulian dan perhatian, penilaian positif dan dorongan semangat dan bantuan materi yang dibantu oleh Dinas Sosial dan Kementrian Sosial RI serta bantuan jasa, nasehat serta interaksi sosial di berbagai aktivitas sosial. Ketika anak jalanan merasa 
dihargai, dinilai positif serta diberikan semangat oleh orang di sekitarnya khususnya dalam penelitian ini pihak Rumah Singgah, maka mereka akan lebih yakin dalam memandang masa depan. Anandar, R., Wibhawa, B. dan Wibowo, H. (2015) mengatakan bahwa kebutuhan anak jalanan akan dukungan sosial sangat penting. Dengan adanya dukungan sosial maka kesehatan anak jalanan baik kesehatan fisik serta mental akan terjaga dan lebih baik.

Hasan (2017) memberikan gambaran yang relatif kuat tentang bagaimana anak jalanan di Bangladesh meyakini dirinya mampu melewati pelecehan sehari hari dengan memanfaatkan dukungan sosial. Dukungan sosial memberikan kekuatan anak jalanan untuk dapat meningkatkan keyakinan bahwa dirinya mampu menghadapi masalah. Peterson, S., Hannah G., Dawn K., Fairchild, A., dan Horn, M. L. (2013) menemukan bahwa dukungan sosial memberikan pengaruh signifikan terhadap aktivitas fisik remaja melalui variabel self-efficacy. Self-efficacy secara langsung dipengaruhi oleh dukungan sosial untuk meningkatkan aktivitas fisik seorang remaja. Penelitian tersebut memaparkan bahwa dukungan sosial memberikan prediksi $10-25 \%$ pada variabel self-efficacy.

Berdasarkan fenomena yang telah dikemukakan dan uraian dari penelitian sebelumnya, penulis tertarik untuk melakukan penelitian dengan judul "Optimisme dan Dukungan Sosial terhadap Self-efficacy Anak Jalanan".

\section{Metode}

Populasi dalam penulisan ini adalah 2.975 jiwa anak jalanan yang dibina di 24 rumah singgah yang tersebar di DKI Jakarta. Data populasi tersebut didapatkan penulis dari Bidang Rehabilitasi Dinas Sosial Provinsi DKI Jakarta yang beralamat di Jalan Gunung Sahari II No. 6, Jakarta Pusat pada tahun 2019. Kemudian penulis juga melakukan pengambilan data di dua rumah singgah yang berada di Tangerang Selatan, total keseluruhan anak jalanan yang ada di dua rumah singgah tersebut berjumlah 90 anak. Data penyebaran populasi pada penulisan ini dapat dilihat dibagian lampiran penulisan.

Anak jalanan yang dijadikan responden penulisan ini merupakan 103 sampel anak jalanan yang diambil dengan teknik non-probability sampling dengan bentuk sampling purposive yaitu teknik penentuan sampel dengan pertimbangan tertentu. Penggunaan purposive sampling dipakai agar penulis mendapatkan sampel dengan kriteria yang ditentukan dari hasil observasi penulis di rumah singgah dan panti sosial sebelum dilakukannya penyebaran kuesioner. Berikut adalah kriteria sampel yang telah penulis tentukan :

a. Berusia 13-18 tahun

b. Tidak tinggal menetap dengan keluarga

c. Memiliki kegiatan ekonomi dijalan maupun ditempat umum

\section{Hasil Penelitian}

Pengujian hipotesis pertama adalah melihat besaran $R$-square $\left(\mathrm{R}^{2}\right)$ untuk mengetahui berapa persen (\%) varians dependen variabel yang dijelaskan oleh independen variabel. Sebagaimana disebutkan dalam tabel 1, dapat dilihat bahwa perolehan $R$-square sebesar 0.729 atau $72.9 \%$. Artinya, proporsi varians terhadap variabel self-efficacy yang diberikan oleh variabel optimisme dan 
dukungan sosial dalam penelitian ini sebesar $72.9 \%$, sedangkan $27.1 \%$ sisanya dipengaruhi oleh variabel lain diluar penelitian ini.

Tabel 1

$R$-Square

\begin{tabular}{lcccc}
\hline Model & $\mathbf{R}$ & R Square $\left(\mathbf{R}^{2}\right)$ & $\begin{array}{c}\text { Adjusted } \mathbf{R} \\
\text { Square }\end{array}$ & $\begin{array}{c}\text { Std. Error of } \\
\text { the Estimate }\end{array}$ \\
\hline 1 & $.854^{\mathrm{a}}$ & .729 & .709 & 7.02368 \\
\hline
\end{tabular}

Selanjutnya penulis menguji apakah keseluruhan independent variable dalam penelitian ini memiliki pengaruh yang signifikan terhadap self-efficacy dari hasil uji F. Adapun hasil uji $\mathrm{F}$ tersebut dapat dilihat pada tabel 2 berikut ini :

Tabel 2

Anova

\begin{tabular}{lccccc}
\hline Model & Sum of Squares & df & $\begin{array}{c}\text { Mean } \\
\text { Square }\end{array}$ & F & Sig. \\
\hline 1 Regression & 6474.847 & 7 & 924.978 & 36.468 & $.000^{\mathrm{b}}$ \\
Residual & 2409.574 & 95 & 25.364 & & \\
Total & 8884.420 & 102 & & & \\
\hline
\end{tabular}

Sebagaimana disebutkan dalam tabel 2, dapat dilihat bahwa nilai p (Sig.) pada kolom paling kanan adalah $\mathrm{p}=0.000$ dengan nilai $\mathrm{p}<0.05$. Sedangkan diketahui bahwa syarat terpenuhinya nilai Sig. Adalah $<0.05$, maka hipotesis mayor yang berbunyi "ada pengaruh yang signifikan dari optimisme (permanence,pervasiveness dan personalization) dan dukungan sosial (dukungan emosional atau penghargaan, dukungan nyata atau instrumental, dukungan informasional dan dukungan persahabatan) terhadap self-efficacy"diterima.

Langkah terakhir yang peneliti lakukan adalah melihat koefisien regresi dari masing-masing variabel bebas (independent variable). Jika nlai $\mathrm{p}<0,05$ maka koefisien regresi yang dihasilkan memiliki pengaruh yang signifikan terhadap penggunaan media sosial, begitupun sebaliknya. Besaran koefesien regresi dari masing-masing variabel bebas (independent variable) terhadap penggunaan media sosial untuk informasi dapat dilihat pada tabel 3 berikut ini : 
Tabel 3

Koefisien Regresi

\begin{tabular}{|c|c|c|c|c|c|}
\hline \multirow{2}{*}{ Model } & \multicolumn{2}{|c|}{$\begin{array}{l}\text { Unstandardized } \\
\text { Coefficients }\end{array}$} & \multirow{2}{*}{$\begin{array}{c}\text { Standardized } \\
\text { Coefficients }\end{array}$} & \multirow{2}{*}{$\mathrm{T}$} & \multirow{2}{*}{ Sig. } \\
\hline & $\mathrm{B}$ & $\begin{array}{l}\text { Std. } \\
\text { Error }\end{array}$ & & & \\
\hline (Constant) & -7.092 & 3.693 & & -1.920 & .058 \\
\hline Permanence & .252 & .089 & .248 & 2.813 & .006 \\
\hline Pervasiveness & .154 & .087 & .143 & 1.771 & .080 \\
\hline Personalization & .083 & .103 & .072 & .807 & .422 \\
\hline $\begin{array}{l}\text { Dukungan emosional dan } \\
\text { penghargaan }\end{array}$ & .186 & .111 & .160 & 1.667 & .099 \\
\hline $\begin{array}{l}\text { Dukungan nyata atau } \\
\text { instrumental }\end{array}$ & .254 & .065 & .255 & 3.886 & .000 \\
\hline Dukungan informasional & .076 & .091 & .069 & .842 & .402 \\
\hline Dukungan persahabatan & .137 & .086 & .126 & 1.604 & .112 \\
\hline
\end{tabular}

Self-efficacy $=-7.092+0.252($ permanence $)+0.154($ pervasiveness $)+.083($ personalization $)+$ 0.186 (dukungan emosional atau penghargaan) $+\mathbf{0 . 2 5 4}$ (dukungan nyata atau instrumental $)+0.076($ dukungan informasional $)+0.137($ dukungan persahabatan $)+e$

Sebagaimana disebutkan dalam tabel hasil tabel 3, uji regresi dalam penelitian ini melihat ada dua dimensi yang memengaruhi self-efficacy (sig < 0.050); satu dimensi dari variabel optimisme yaitu permanence (0.006) dan satu dimensi dari variabel dukungan sosial yaitu dukungan nyata atau instrumental (0.000).

\section{Diskusi}

Berdasarkan penelitian ini berusaha untuk menjawab permasalahan yang telah dirumuskan sebelumnya yaitu mengetahui pengaruh optimisme dan dukungan sosial terhadap self-efficacy anak jalanan. Self-efficacy dengan sangat jelas memberi wawasan baru tentang suatu aspek mental yang menjadi penghubung antara potensi yang dimiliki seseorang dengan hasil akhir. Mengingat variabel self-efficacy memegang peran penting dalam mengoptimalkan potensi individu, hal ini tentu tidak terlepas dari faktor internal dan eksternal yang dapat memengaruhi variabel tersebut. Oleh karenanya, penelitian ini dilakukan untuk melihat pengaruh internal yaitu optimisme dan pangaruh eksternal yaitu dukungan sosial terhadap variabel self-efficacy.

Berdasarkan hasil penelitian, self-efficacy dikategorikan pada tingat tinggi, artinya anak jalanan yang memiliki self-efficacy yang kuat berjumlah lebih dari setengah populasi yang diteliti. Hal ini berhubungan dengan penelitian yang dilakukan oleh Chairani et.al (2019) bahwa self-efficacy menjadi faktor yang memotivasi anak jalanan dapat memecahkan masalah mereka. Anak jalanan dengan self-efficacy yang tinggi akan berusaha untuk mengembangkan fungsi kognitif dan moral untuk membentuk persepsi positif tentang diri mereka sendiri dan keyakinan tentang kemampuan mereka dalam mencapai tujuan yang diharapkan.

Salah satu variabel bebas dalam penelitian ini adalah optimisme. Ditemukan bahwa optimisme secara signifikan berpengaruh terhadap self-efficacy. Hal ini berhubungan dengan penelitian yang 
dilakukan Robinson dan Snipes (2009), Yeo (2012), dan Harjot (2015) yang menemukan korelasi positif antara variabel optimisme dan self-efficacy. Temuan ini juga sesuai dengan literatur coping remaja yang mengungkapkan bahwa remaja dengan optimisme yang baik cenderung menampilkan perilaku dan strategi yang lebih efektif ketika berurusan dengan tekanan di sekolah dan situasi lain (Roesch, Vaughn, Aldridge, \& Villodas, 2009; Suldo, Shaunessy, \& Hardesty, 2008)

Ditemukan bahwa satu dari tiga dimensi optimisme secara signifikan memengaruhi self-efficacy, yaitu dimensi permanence. Dimensi permanence memiliki nilai koefisien regresi dengan arah positif yang menjelaskan bahwa semakin tinggi permanence maka semakin tinggi self-efficacy individu. Yeo (2012) menemukan bahwa adanya keterkaitan yang kuat antara permanence dan selfefficacy pada remaja. Weiner (1972) menjelaskan bahwa permanence berkontribusi terhadap tingkat motivasi dan harapan yang lebih besar dari keberhasilan untuk masa depan. Anak jalanan dengan permanence yang tinggi akan berusaha lebih keras setelah mereka mengalami keberhasilan, sedangkan remaja dengan permanence yang rendah melihat sebuah kesuksesan sebagai suatu kebetulan. Semakin tinggi permanence anak jalanan maka semakin tinggi pula keyakinan bahwa dirinya mampu melewati kesulitan atau hambatan.

Sementara itu, dimensi pervasiveness pada penelitian ini ditemukan tidak memiliki pengaruh signifikan terhadap self-efficacy. Temuan ini tidak sejalan dengan penelitian Flammer (2001) yang mengungkapkan bahwa pervasiveness penting untuk membantu individu membangun dan mempertahankan keyakinan self-efficacy pada tingkat tinggi, dan untuk membimbing individu yang gagalmengekspos pada pengalaman positif. Pervasiveness akan menunjukkan kecenderungan untuk menghancurkan kegagalan dengan harapan bahwa hal-hal negatif tidak akan terjadi dalam aspek kehidupan lainnya (Kelley, 1972). Temuan ini dapat terjadi karena pandangan negatif dari keluarga, masyarakat dan diri sendiri dapat menghambat anak jalanan untuk mengetahui dalam mengetahui area kemampuan dalam dirinya. Stigma tersebut memiliki kecenderungan dengan pemecahan masalah yang buruk, keterasingan sosial, dan pengambilan keputusan yang berhubungan dengan pengetahuan akan kemampuan diri (Peterson, Maier \& Seligman, 1993).

Kemudian dimensi personalization pada penelitian ini juga tidak memberikan pengaruh yang signifikan terhadap self-effcacy. Hal ini tidak sejalan dengan penelitian Yeo (2012) yang menemukan korelasi positif antara personalization dan self-efficacy. Seharusnya individu yang memiliki keyakinan adalah ketika individutersebut memiliki kendali atas sesuatu yang sedang dijalaninya dan kemudian percaya bahwa faktor dari dirinya yang menciptakan suatu keberhasilan (Seligman, 1975). Temuan ini dapat terjadi karena kehidupan yang cenderung rentan terhadap masalah-masalah sosial, seperti pelecehan seksual, eksploitasi anak, dan perdagangan narkoba membuat anak jalanan kesulitan dalam mengetahui sumber keberhasilan yang telah didapatkan. Sementara itu, mereka yang dapat menghindari penyalahgunaan narkoba atau masalah-masalah sosial lainnya seringkali dapat mengembangkan keterampilan pribadi dan harga diri yang cukup besar (Aptekar, 1994; Ribeiro \& Ciampone, 2001).

Variabel independen selanjutnya dalam penelitian ini adalah dukungan sosial. Ditemukan bahwa dukungan secara signifikan berpengaruh terhadap self-efficacy dengan arah korelasi positif, artinya semakin tinggi dukungan sosial yang diterima anak jalanan maka semakin tinggi pula self-efficacy pada anak jalanan tersebut. Hal ini sejalan dengan penelitian yang dilakukan oleh Peterson et.al (2013) yang menemukan bahwa dukungan sosial memberikan pengaruh yang signifikan terhadap self-efficacy remaja. Teori sosial kognitif (Bandura, 1986) mengemukakan bahwa dukungan sosial 
yang kuat akan meningkatkan self-efficacy individu untuk mengatasi hambatan. Dukungan sosial yang diterima anak jalanan akan membantu anak jalanan menguatkan self-efficacy yang digunakannya untuk mengatasi kesulitan.

Menariknya, hanya terdapat satu jenis dukungan sosial yang berpengaruh secara signifikan terhadap self-efficacy yaitu dukungan nyata atau instrumental. Hal ini sejalan dengan penelitian yang dilakukan oleh Peterson (2013) yang menemukan bahwa dukungan nyata atau instrumental memiliki pengaruh terhadap self-efficacy remaja. Cutrona (1990) yang menjelaskan bahwa dukungan sosial sangat efektif ketika jenis dukungan yang ditawarkan cocok dengan penerima, beberapa situasi memerlukan berbagai bentuk dukungan yang berbeda. Sarafino (2011) menjelaskan bahwa dukungan nyata atau instrumental adalah dukungan yang paling efektif dalam kasus individu yang berada dalam tekanan atau rintangan.

Dukungan nyata atau instrumental melibatkan bantuan langsung, seperti ketika orang lain memberi atau meminjamkan uang, atau membantu dengan menyelesaikan tugas-tugas disaat stress. Anak jalanan memiliki status marjinal (terpinggirkan) dan merasakan kerasnya jalanan, dan karenanya dia tidak bisa berbuat banyak untuk melindungi diri dari masalah-masalah sosial. Untuk dapat menangani masalah tersebut, anak jalanan akan mencari keadilan dengan kapasitas mereka yang sederhana yaitu mencari bantuan nyata dari pihak rumah singgah, panti sosial, masyarakat dan orang tua. Dukungan instrumental merupakan bentuk dukungan protektif telah dilaporkan efektif dalam menangani kasus anak jalanan beberapa penelitian lain (Conticini, 2005; Mizen \& Ofosu, 2010).

Sementara itu, dukungan emosional, informasional dan persahabatan dalam penelitian ini ditemukan pengaruh yang tidak signifikan terhadap self-efficacy anak jalanan. Hal ini tidak sejalan dengan penelitian yang dilakukan oleh Hasan (2017) yang memberikan gambaran yang relatif kuat tentang bagaimana anak jalanan di Bangladesh meyakini dirinya mampu melewati pelecehan sehari-hari dengan memanfaatkan dukungan emosional, informasional, dan persahabatan dari jaringan sosial mereka. Temuan ini dapat terjadi karena penelitian yang dilakukan penulis berada di Indonesia dan memiliki budaya yang berbeda. Ditambah kriteria responden yang ditetapkan adalah anak jalanan yang dibina di rumah singgah atau panti sosial, di mana pada tempat tersebut keseharian anak jalanan relatif lebih terhindar dari pelecehan. 


\section{Daftar Pustaka}

Alfianita, N. (2016). Optimisme anak jalanan dalam menghadapi masa depan. Skripsi. Fakultas Psikilogi. Universitas Muhammadiyah Surakarta. Retrieved from http://eprints.ums.ac.id/46677/1/naskah\%20publikasi.pdf

Anandar, R., Wibhawa, B., \& Wibowo, H. (2015). Dukungan sosial terhadap anak jalanan di rumah singgah. Share Social Work Journal, 5(1), 1. doi:10.24198/share.v5i1.13122.

Aptekar, L. (1994). Street children in the developing world: a review of their condition. Cross Cultural Research. 28(3), 195-224. doi:10.1177/106939719402800301.

Astuti, D. (2004). Upaya pemberdayaan anak jalanan. Surabaya: Unair.

Bandura, A. (1986). Social foundations of thought and action: A social cognitive theory. New York: Prentice Hall.

Bandura, A. (1997). Self-efficacy the exercise of control. New York: W. H. Freeman and Company.

Chairani, R., Hamid, A. Y. S., Sahar J. \& Budhi, T. E., (2019). Self-efficacy of street children in jabodetabek in utilizing health services. IOP Conf. Series: Earth and Environmental Science, 1, 248. doi:10.1088/1755-1315/248/1/012023

Conticini, A. (2005). Urban livelihoods from children's perspectives: Protecting and promoting assets on the streets of Dhaka. Environment andUrbanization, 17, 69-81. doi: $10.1177 / 095624780501700206$

Cutrona, C. E. (1990). Stress and social support - In search of optimal matching. Journal of Social and Clinical Psychology, 9(1), 3-14.doi:10.1521/jscp.1990.9.1.3

Flammer, A. (2001). Self-efficacy: self-development in childhood. International Encyclopedia of the Social \& Behavioral Sciences. 13812-13815.doi:10.1016/B0-08-043076-7/01726-5

Harjot, K. D. (2015). Study of self-efficacy and optimism of b.ed. students. European Journal of Academic Essays, 2(9), 102-107. Retrieved from https://www.academia.edu/25288553/Study_of_Selfefficacy_and_Optimism_of_B.Ed._Students

Hasan, M. D. (2017): Street children's use of social support against everyday abuse in Bangladesh. Child\&YouthServices. doi:10.1080/0145935X.2017.1326307

Mizen, P., \& Ofosu, K., Y. (2010). Asking, giving, receiving: Friendship as survival strategy among Accra's street children. Childhood, 17, 441-454. doi:10.1177/0907568209350511

Multasih, E. (2013). Pengaruh Self-Esteem dan Dukungan Sosial Terhadap Optimisme Masa Depan Anak Jalanan di Rumah Singgah Jakarta Selatan. Tazkiya: Journal of Psychology, $1,1$. doi:10.15408/tazkiya.v18i1.9377

Peterson, S., Hannah G., Dawn K., Fairchild, A., dan Horn, M. L. (2013). The Association of SelfEfficacy and Parent Social Support on Physical Activity in Male and Female Adolescents. Health Psychology, 32(6), 666-674 doi:10.1037/a0029129 
Peterson, C., Maier, S. F., \& Seligman, M. E. P. (1993). Learned helplessness: Atheory for the age of personal control. New York: Oxford University Press.

Ribeiro, O. M. and Ciampone, T. M. H. (2001), Homeless Children: The Lives of a Group of Brazilian Street Children, Journal of Advanced Nursing 35(1), 42-49. doi:10.1046/j.13652648.2001.01847.x

Roesch, S.C., Vaughn, A.A., Aldridge, A.A., \& Villodas, F. (2009). Daily diaries and minority adolescents: Random coefficient regression modeling of attributional style, coping, and affect. International Journal of Psychology, 44, 393-400. doi:10.1080/00207590802644758

Sanji, W. M. (2018). Resilience and the re-integration of street children and youth in sub-saharan africa. Cameroon: Springer Briefs in Psychology.

Sarafino, E. P., Timothy W. Smith. (2011). Health psychology biopsychosocial interactions seventh edition. United States of America: Laserwords.

Seligman, M. E. P. (1975). Helplessness. on depression, development and death. San Francisco: Freeman.

Suldo, S.M., Shaunessy, E., \& Hardesty, R. (2008). Relationships among stress, coping, and mental health in high-achieving high school students. Psychology in the Schools, 45, 273-290. doi:10.1002/pits.20300

Walgito, B. (2010). Pengantar psikologi umum. Yogyakarta: Andi Offset.

Weiner, B. (1972). Theories of motivation: From mechanism tocognition. Morristown, NJ: General Learning Press.

Yeo, L. S. (2012). Attributional style and self-efficacy in singaporean adolescents. National Institute of Education, Nanyang Technological University, Singapore, 22(1), 82-101. doi:10.1017/jgc.2012.1 